Bull. Iraq nat. Hist. Mus.

(2021) 16 (3): 359- 387.

https://doi.org/10.26842/binhm.7.2021.16.3.0359

\title{
MULTIVARIATE ANALYSIS OF THE STEM ANATOMICAL CHARACTERS OF \\ TERMINALIA L. (COMBRETACEAE) \\ IN EGYPT
}

\author{
Nahed Waly* Heba Moustafa** Rim Hamdy* and Ashraf Soliman* \\ *Department of Botany and Microbiology, Faculty of Science, Cairo University, Giza, \\ Egypt. \\ **National Organization for Drug and Control Research, Giza, Egypt. \\ •Corresponding author: rimhamdy@sci.cu.edu.eg
}

Received Date: 20 April 202 1, Accepted Date: 4 June 2021, Published Date: 20 Jun 2021

\section{ABSTRACT}

A comparative investigation of the anatomical characters through a microscopical examination of the prepared transverse sections of the stem was carried out. Six plates with 32 photomicrographs were provided to convincingly show the considerable variations of anatomical characters within the nine examined species. The matrix of 18 anatomical characters which included nine quantitative and nine qualitative was applied for the clustering analysis (CA) followed by the principal component analysis (PCA) using the Multivariate Analysis of Ecological Data, PC-ORD.

The results exhibited significant variations among the species resulting in the construction of an artificial key; this key accurately represents a sufficient tool to display the considerable variation among the recognized species prominently. The distinction between Terminalia L., 1767 species based on significant variations in the elements of stem anatomy; axial parenchyma and ray characteristics were considered as important parameters, while vessel diameter, fiber wall thickness, etc. were considered minor characters to differentiate between the studied species. The potential usefulness of the differentiation of these species properly maintains a profound efficiency in pharmaceutical and traditional medicine.

Keywords: Combretaceae, Paratracheal axial parenchyma, Stem anatomy; Terminalia; Two-way clustering analysis.

\section{INTRODUCTION}

Terminalia L., 1767 the second largest genus of Combretaceae, is derived from the Latin name (Terminus = end) which means the appearance of the leaves at the end of the shoots (van Wyk and van Wyk, 1997; Saxena et al., 2013). The genus comprises 150 species worldwide distributed in pantropic regions (Exell and Stace, 1966; Wickens, 1973; McGaw et al., 2001; Tan et al., 2002; Heywood et al., 2007; Stace, 
Multivariate analysis of the stem

2007). Approximately fifty species of this genus are native throughout eastern, southern, and western Africa (Lebrun and Stork, 1991). It is represented in Egypt by nine cultivated species.

The archaeological excavations at Quseir al-Qadim (an ancient port located on the Red Sea coast of Egypt in the Roman, and medieval Islamic periods) revealed the presence of two Terminalia species among the tropical species utilized in traditional medicine and cuisine. Terminalia bellerica (Gaertn.) Roxb., 1805 was traded during the early Roman period (1st to early 3rd centuries AD); in addition to T. chebula Retz., 1789 continue as imports in the medieval Islamic period (11-13 ${ }^{\text {th }}$ Century onwards) (van der Veen and Morales, 2015). During the $19^{\text {th }}$ Century, Terminalia species had introduced to Egypt as ornamental and avenue trees (Delchevalerie, 1899; Sickenberger, 1901; Bircher, 1960). In the meantime, it plays a role in the environmental services (e.g., absorbing air pollutants, sequestering carbon, producing shade and oxygen). Terminalia arjuna (Roxb.) Wight and Arn., 1834, T. bellerica and T. catappa L., 1767 are planted in the Egyptian wooden forests irrigated with primary level treated sewage water (Imam, 1983). Referring to their economic importance in Egypt; the wood is used for house building, making furniture (T. chebula), and agricultural implements (T. arjuna); the bark is an essential source of tannins used for tanning and dyeing ( $T$. arjuna) and the fruits are used to cure many ailments ( $T$. bellirica and T. chebula). The taxonomic revision of genus Terminalia in Egypt revealed the presence of nine cultivated species (Sickenberger, 1901; Muschler, 1912, Hamdy et al., 2007; Hamdy, 2010; Youssef and Hamdy, 2013).

According to its commercial interest, there are several studies on wood characteristics of the genus with some attempts to differentiate between Terminalia species (Metcalfe and Chalk, 1950; Normand and Paquis, 1976; van Vliet, 1979; Rajput and Rao, 1999; Tilney, 2002; Gupta and Singh, 2005; Singh and Sharma, 2013; Ingle and Dhabe, 2015). Despite all previous wood studies, Terminalia, in general, vary significantly in morphology, anatomy, and karyotype characters (Gill et al., 1982; AL-Mayah, 1983; Jansen et al., 1995; Ohri 1996; Schmidt and McCleland 2002; Sarkar et al., 2016). Many taxonomic studies are still controversial regarding this genus since it never has a taxonomical congruence to classify it into subgenera and sections (Tan et al., 2002; Akinsulire et al., 2018).

As a result of the problematic taxonomic status of the genus including a significant variation, overlapping, and the difficulty in identifying many genus members morphologically (Oladipo and Akinloye, 2018), especially if a leafy or flowering twig is subjected to observation, this work may be useful to confirm the identification of fragments of the species. It is necessary to search for a successful study to distinguish species reliably. In general, anatomical studies perform a substantial source for taxonomic inferences in various groups of flowering plants (Keshavarzi and Zare, 2006; Edeoga et al., 2007; Guimarães et al., 2007; Kaplan et al., 2007). 
Waly et al.

Apart from Waly et al. (2020) study based on the anatomical features of petiole and leaf, no comprehensive stem anatomical study to differentiate the Terminalia species was done in Egypt yet. Therefore, the core objective of this study is to combine the available information of anatomical features, investigate, discover the relations and possible variations among the nine species belonging to this genus in Egypt, based on the stem anatomical characters and try to provide an artificial key to differentiate between those species.

\section{MATERIAL AND METHODS}

\section{Specimens' preparations}

The plant materials collected from different botanical gardens in Cairo and Giza Provinces were studied, compared with authenticated materials kept in different Egyptian herbaria. The herbarium specimens were preserved with new voucher numbers and kept at the Cairo University Herbarium (CAI) as appended in Table (1).

These wood samples were boiled merrily in water for about two hours to soften them. Each wood sample was then shaped and sized into a woodblock of $2 \times 2 \times 3 \mathrm{~cm}$. Transverse and radial sections from the pith to bark at $10-15 \mu \mathrm{m}$ thickness were obtained at the laboratory using a microtome. Permanent wood tissue slides were prepared after dehydrating and staining with light green and safranin, and then mounted using Canada balsam according to the standard procedure of the light microscope (Johansen, 1940). After that, the completed sections were carefully examined using an Olympus BX51 light microscope. Photomicrographs were taken using an Olympus DP12 in the Central Laboratory of Geology Department, Faculty of Science - Cairo University. The terminology of the anatomical characters of the stem was described correctly according to Metcalfe and Chalk (1950), Tilney (2002), and Akinsulire et al. (2018). The measurements for each character were based on more than 30 readings in an area of $25 \mathrm{~mm} 2$ field of view, following the IAWA Committee (1989).

Many authors implemented multivariate analysis in classifying problematic taxa (Sneath and Sokal, 1973; Chiapella, 2000; Gémez- Campo et al., 2001; Rahman et al., 2013; Teleb and Salah El-din, 2014; Yaradua et al., 2018). Cluster analysis (CA) and principal component analysis (PCA) are the most common techniques used in numerical classifications. Cluster analysis aims to arrange a set of characters (objects) in the same group (called a cluster) in a way more closely related than characters in other groups (clusters). PCA is a method used to reduce the original data dimensions. It reflects the most extensive variability within the data by determining a line through the cloud of points. The location of the points relative to one another is a sign of their taxonomic relation. The PCA enables the relationship to be visually interpreted. The complex matrix of 18 anatomical characters: 9 quantitative and 9 qualitative of the investigated Terminalia species is subjected to the Multivariate Analysis of Ecological Data, PC-ORD for window, version 5.0. The two-way cluster analysis was adopted, using the Sorensen (Bray-Curtis) as a distance measure with the Flexible Beta as a 


\section{Multivariate analysis of the stem}

group linkage method. It is to be noted that the qualitative character of the paratracheal axial parenchyma is divided into four different types (a multistate character). Distribution among the nine species was as following: aliform confluent to banded (ACB), vasicentric scanty (VS), vasicentric to banded (VB) and vasicentric to aliform (VA) to comply with the clustering analysis. The qualitative anatomical characters were transformed into binary characters $(0,1)$ to allow cluster analysis techniques, followed by the generalization of an artificial key depending on the anatomical characters investigated.

Table (1): The locality of collected specimens, date of collection, collector name and voucher number of the investigated Terminalia species are kept at Cairo University Herbarium (CAI).

\begin{tabular}{|c|c|c|c|c|}
\hline No. & Species & Locality & $\begin{array}{l}\text { Date of } \\
\text { collection }\end{array}$ & $\begin{array}{c}\text { Collector and } \\
\text { voucher } \\
\text { number } \\
\end{array}$ \\
\hline 1 & T. arjuna & $\begin{array}{l}\text { Giza: Zoological } \\
\text { garden }\end{array}$ & 7 Nov. 2016 & $\begin{array}{l}\text { H. Moustafa } \\
5067\end{array}$ \\
\hline 2 & T. bellirica & $\begin{array}{l}\text { Giza: Zoological } \\
\text { garden }\end{array}$ & 7 Nov. 2016 & $\begin{array}{l}\text { H. Moustafa } \\
5068\end{array}$ \\
\hline 3 & T. bentzoe & $\begin{array}{l}\text { Giza: Zoological } \\
\text { garden }\end{array}$ & 7 Nov. 2016 & $\begin{array}{l}\text { H. Moustafa } \\
5069 \\
\end{array}$ \\
\hline 4 & T. brownii & $\begin{array}{l}\text { Giza: Mazhar botanical } \\
\text { garden }\end{array}$ & $\begin{array}{l}10 \text { Dec. } \\
2016\end{array}$ & $\begin{array}{l}\text { H. Moustafa } \\
5070\end{array}$ \\
\hline 5 & T. catappa & $\begin{array}{l}\text { Giza: Orman botanical } \\
\text { garden }\end{array}$ & 7 Nov. 2016 & $\begin{array}{c}\text { H. Moustafa } \\
5071 \\
\end{array}$ \\
\hline 6 & T. laxiflora & $\begin{array}{l}\text { Cairo: El Zohriya } \\
\text { garden }\end{array}$ & $\begin{array}{l}16 \text { Nov. } \\
2016\end{array}$ & $\begin{array}{l}\text { H. Moustafa } \\
5072\end{array}$ \\
\hline 7 & T. mantaly & $\begin{array}{l}\text { Giza: Mazhar } \\
\text { botanical garden }\end{array}$ & $\begin{array}{l}10 \text { Dec. } \\
2016\end{array}$ & $\begin{array}{l}\text { H. Moustafa } \\
5073 \\
\end{array}$ \\
\hline 8 & T. muelleri & $\begin{array}{l}\text { Giza: Zoological } \\
\text { garden }\end{array}$ & 7 Nov. 2016 & $\begin{array}{l}\text { H. Moustafa } \\
5074\end{array}$ \\
\hline 9 & T. myriocarpa & Giza Zoological garden & 7 Nov. 2016 & R. Hamdy 5075 \\
\hline
\end{tabular}

\section{RESULTS}

The general anatomical structure of the stem was more or less similar across the nine species of Terminalia. All species exhibited normal secondary growth as secondary phloem, secondary xylem, and cork. However, some of them still contained an outermost epidermal layer with hair during their secondary development.

\section{Stem in transverse section}

Trichomes, when present, combretaceous type. Cork arising superficially from parenchyma cells as a cortical origin. Cuticle very thin to occasionally thin (0.1-3.0 $\mathrm{mm})$. The epidermal cells anticlinal elongated to a more or less papillate due to the convex periclinal cell walls, sometimes with square or brick-shaped. Cortex one or two types of cells that formed of outer collenchyma and inner parenchyma cells. Druse crystals nearly always present. Pericycle in the form of islands composed of 4 or 5(-10) fiber layers, situated around broad inner parenchyma, almost always with secondary 
Waly et al.

phloem fibers in 1-4 interrupted bands. Phloem and xylem form a continuous cylinder traversed by narrow rays. External phloem accompanies with primary phloem fibers formed isolated groups or continuous band occasionally with secondary phloem sclerenchyma elements in an interrupted band forming 1-3 cell layers thick and arranged in tangential bands in transverse section; secondary phloem fibers often made up of bands of 4 or 5-10) cell layers thick. In the more commonly studied species, fibers are prominent in the secondary phloem tending to occur in groups. Internal phloem (intraxylary phloem) present in separate bands of varying sizes or forming a continuous ring. Intercellular canals of the vertical traumatic type (lysogenous ducts) at the periphery portion of the pith in some studied species. Tylosis was abundant. Pith usually parenchymatous or parenchyma cells with a few to several lignified cells.

\section{Wood}

Wood usually medium-sized, begging with the ring without vessels in some species. In T.S.: vessels of all species with simple perforations oval to round shape and the majority was solitary and in radial multiples. Parenchyma was typically abundant, predominantly paratracheal, and possibly apotracheal. The paratracheal parenchyma varied from vasicentric scanty and aliform to regular or irregular confluent bands. Apotracheal parenchyma in some isolated cells scattered among the fibers in some species. Fibers varied from very thin-walled to thin- to thick-walled. In L.S.: Rays composed of procumbent square or upright cells; exclusively uniseriate occasional biseriate portions; homocellular or heterocellular. No inclusions present in ray or axial parenchyma cells.

\section{Diagnostic descriptive features}

Trichomes unicellular, slender, thick-walled, pointed with swollen base ( $T$. catappa, T. bentzoe (L.) L.f., 1781 and T. myriocarpa van Heurck and Müll. Arg., 1871, T. brownii Fresen, 1837 (Pl. 1A). Lenticels found in T. arjuna, T. bentzoe, T. catappa, T. mantaly H. Perrier, 1953and T. muelleri Benth., 1864(Pl. 1B). Cortex formed of one type; parenchymatous tissue cells observed in T. bellerica, T. catappa, T. mantaly and T. muelleri. The two types with outer collenchymatous and inner parenchymatous observed in T. arjuna, T. bentzoe, T. brownii, T. laxiflora Engl. \& Diels, 1900 and T. myriocarpa. Pericycle septate groups of lignified sclerenchyma cells found in all studied species except in T. mantaly. Druses appeared as small crystals in the cortical zone [T. arjuna; (Pl. 1C), T. bentzoe, T. brownii, and T. laxiflora], in addition to the pith (T. muelleri), or phloem region (T. myriocarpa). While druses appeared as large crystals and more abundant in the cortex, phloem and pith regions (T. mantaly). Only T. catappa was characterized by clustered crystals filling large idioblasts (Pl. 1D). Tannins were observed in the cortex of T. arjuna, T. bellerica, T. bentzoe, T. brownii, and T. catappa; in addition to the pith of T. laxiflora (Pl.1E) and T. muelleri, while in T. mantaly recorded only in pith. Tylosis was seen in T. mantaly (Pl. 1F) and $T$. myriocarpa. Intercellular canals of the vertical traumatic type (lysogenous ducts) varied in their number from 3 canals in T. myriocarpa (Pl. 2A), 4 in T. arjuna (Pl. 2B), and T. catappa to 5 in T. muelleri (Pl. 2C). 


\section{Interspecies variation in wood elements}

Vessels were solitary in all studied species except $T$. laxiflora predominately found in radial multiples up to 5-7 vessels. The mean minimum and maximum vessels lumina diameter were $35.7 \mu \mathrm{m} \pm 17$ (T. brownii) and $201 \mu \mathrm{m} \pm 66.6$. Fibers varied from very thin-walled (T. bellerica, T. catappa and T. myriocarpa) to thin- thick-walled ( $T$. arjuna, T. bentzoe, T. brownii, T. laxiflora, T. mantaly, T. muelleri); septate fiber in $T$. arjuna, T. bellerica, T. bentzoe, T. mantaly, T. muelleri (Pl. 2D) or non-septate fiber in T. brownii (Pl.2E), T. catappa, T. laxiflora, and T. myriocarpa. The mean minimum and maximum fiber lumina diameter were $1.96 \mu \mathrm{m} \pm 1.25$ (T. brownii) and $14.8 \mu \mathrm{m} \pm$ 4.4 ( $T$. bellerica).

Fiber wall thickness varied from thin wall $2.41 \mu \mathrm{m} \pm 1.2$ in $T$. arjuna, thick wall $7.89 \mu \mathrm{m} \pm 1.7$ in T. laxiflora, to very thick wall $33.3 \pm 30.9$ in $T$. brownii. Parenchyma: paratracheal varied from vasicentric scanty (T. bellerica, T. bentzoe, T. brownii (Pl.3A), and T. muelleri); vasicentric aliform in T. laxiflora; Pl. 3B); aliformconfluent to banded in T. arjuna (Pl. 3C) to vasicentric- banded in T. catappa, $T$. myriocarpa, and T. mantaly (Pl. 3D). Rays: uniseriate homocellular (T. arjuna and $T$. brownii); uniseriate and biseriate homocellular in T. laxiflora (Pl. 3 E) and T. mantaly or uniseriate heterocellular in T. bellerica, T. bentzoe, T. catappa; $\mathrm{Pl} .3 \mathrm{~F}$, T. muelleri, and T. myriocarpa. The mean minimum and maximum ray height were $58.5 \mu \mathrm{m} \pm$ 16.77 in $T$. brownii and $290 \mu \mathrm{m} \pm 3.8$ in T. arjuna. The mean minimum and maximum ray width were $6.73 \mu \mathrm{m} \pm 0.64$ in $T$. bellerica and $22.7 \mu \mathrm{m} \pm 4$ in T. laxiflora. The mean minimum and maximum ray frequency were $15 \pm 2.1 / \mathrm{mm}^{2}$ in $T$. catappa and 90 $\pm 32.4 / \mathrm{mm}^{2}$ in $T$. arjuna. The mean minimum and the maximum number of cells in each ray varied from $6 \pm 0.42$ cells in $T$. brownii to $15 \pm 0.57$ cells in $T$. bentzoe. The mean minimum and the maximum length of a cell/ray were $6.3 \mu \mathrm{m} \pm 1.95$ (T. mantaly) and $41.4 \mu \mathrm{m} \pm 4.6$ (T. arjuna).

The qualitative and quantitative stem anatomical characters of the 9 Terminalia species are summarized in Table (2). The species are arranged alphabetically at the top of each column and followed by the plate number for the transverse and longitudinal sections (Plates 4-8). Among these features; the axial parenchyma, vessel lumina diameter, fiber wall thickness, and presence of lysogenous ducts, and ray height are distinguishable.

\section{Multivariate Analyses:}

1. Anatomical cluster analysis: The matrix of the 9 Terminalia species and the 18 anatomical characters (Tab. 2) subjected to the two-way hierarchical cluster analysis, using the Sorensen as a distance measure with the Flexible Beta as a group linkage method (Diag.1). In the first way of the hierarchical clustering, vertically arranged in columns with percent chaining $=3.33$, the 18 anatomical characters are subdivided into two main clusters, nine quantitative and nine qualitative. The first included eight qualitative characters cited ones. While the paratracheal axial parenchyma is subdivided into four different sub-characters. The second cluster contained the nine 
Waly et al.

quantitative characters, in which the mean values will be considered. The matrix is coding the brightness of the blue color which indicates the relativization of that character to the corresponding species (the darkest the color, the character maximum). In the other way of hierarchical clustering, horizontally arranged in rows with percent chaining $=11.60$. These are firstly divided into two sub-clusters.

The paratracheal axial parenchyma aliform confluent to banded (PAxP ACB) and the vessel lumina diameter $>200 \mu \mathrm{m}$ considered the most diagnostic features (the pink outlined squares) that separate $T$. arjuna from the eight species. The latter is subdivided into two groups: T. brownii, T. catappa, and T. mantaly in one cluster due to ray height $\leq 100 \mu \mathrm{m}$ and length of a cell/ray $\leq 10 \mu \mathrm{m}$ (outlined green squares). This group is furthermore subdivided into two sub-groups. The first has T. brownii which characterized by paratracheal axial parenchyma vasicentric scanty; among other characters outlined dark brown squares (Diag. 1). The last five species are more subdivided into two sections: T. bellirica and T. myriocarpa, in one section, are characterized by the vessels' lumina diameter $>60 \mu \mathrm{m}$ and fiber wall thickness $<3.5$ $\mu \mathrm{m}$ (outlined yellow squares). The other section is furthermore subdivided into two subsections. The first subsection has one species, namely T. laxiflora and it separated from $T$. bentzoe and T. muelleri by many diagnostic characters. The paratracheal axial parenchyma vasicentric to aliform; uniseriate and biseriate rays (outlined orange squares) [see Table (1) and Diagram (1) for more details]. 
Multivariate analysis of the stem
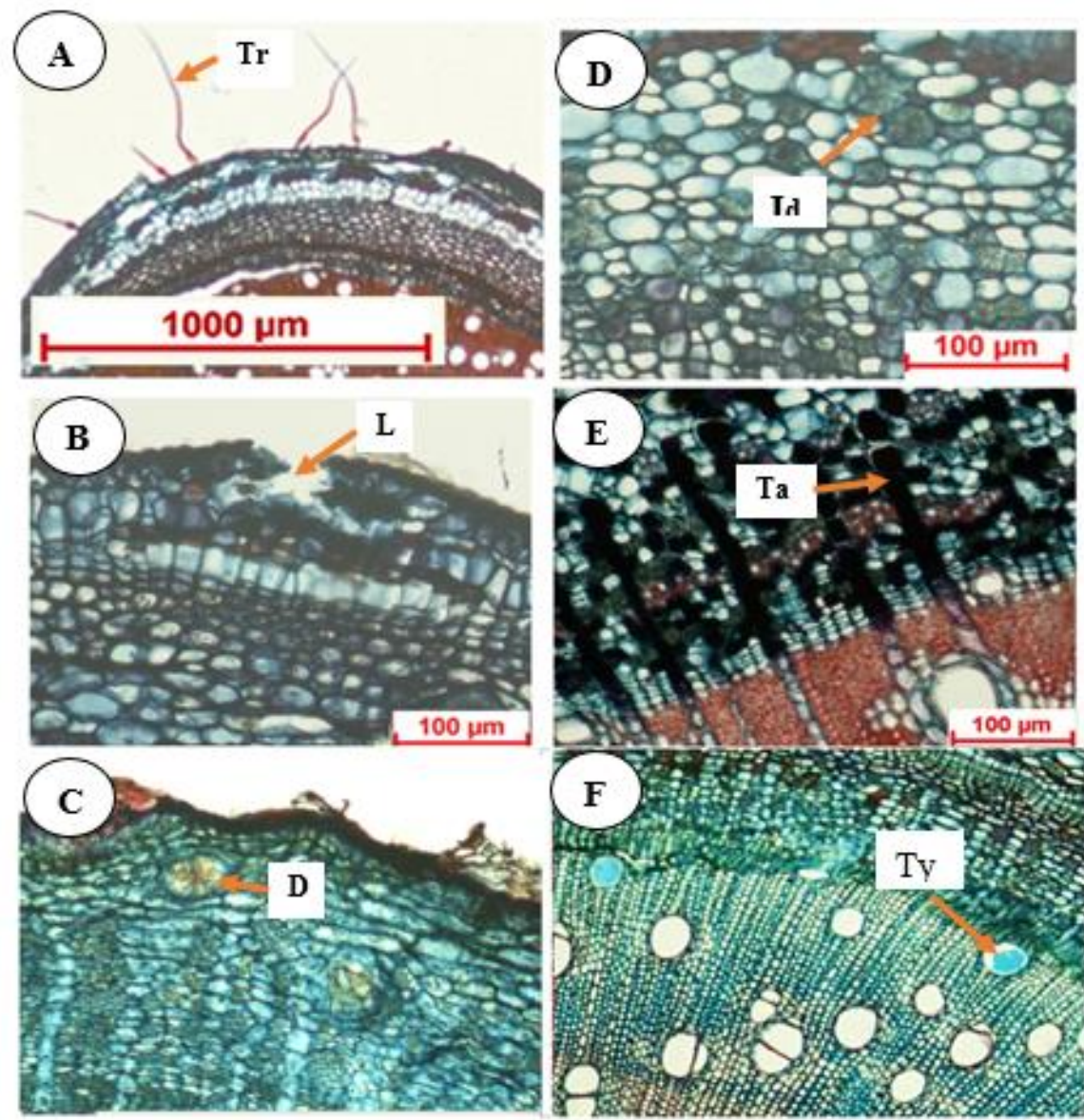

Plate (1): Diagnostic features in Terminalia species; (A) Trichomes in T. brownii;

(B) Lenticel in T. muelleri; (C) Druses in T. arjuna; (D) Clustered crystals filling large idioblasts in T. catappa; (E) Tannins in T. laxiflora;

(F) Tylosis in T. mantaly. (Abbreviations: $\mathrm{D}=$ druses; $\mathrm{Id}=$ idioblasts containing druses; $\mathrm{L}=$ lenticel; $\mathrm{Ta}=$ tannins; $\mathrm{Ty}=$ tylosis) 
Waly et al.

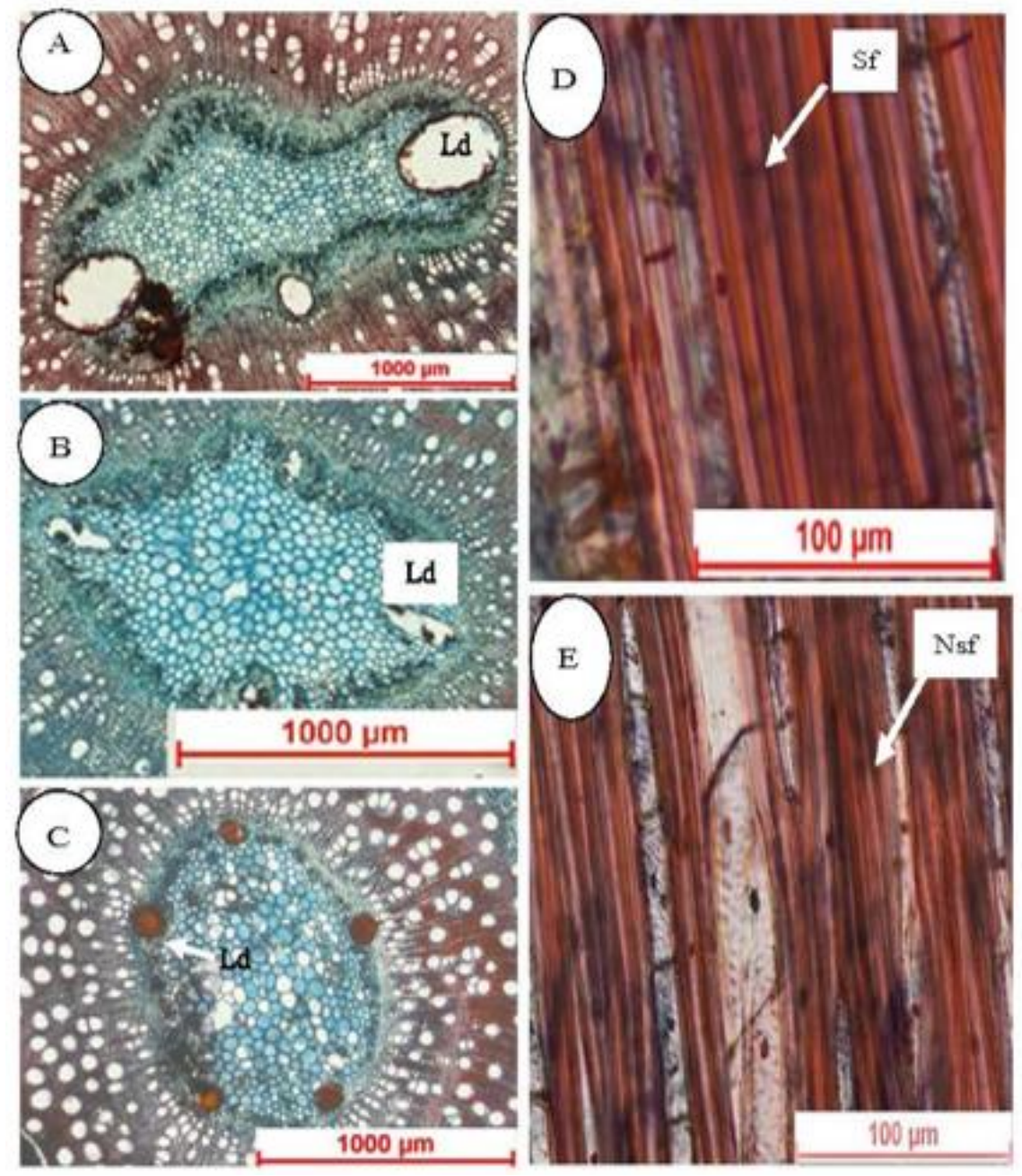

Plate (2): Diagnostic features in Terminalia species; (A-C)intercellular canals lysogenous ducts; (A) 3 ducts in T. myriocarpa; (B) 4 ducts in T. arjuna; (C) 5 ducts in T. muelleri; (D)septatefibres(Sf) in T. muelleri; (E) nonseptatefibres (nsf) in T. brownii. (Abbreviations: $\mathrm{Ld}=$ lysogenous duct; $\mathrm{Nsf}=$ non-septatefibres; $\mathrm{Sf}=$ septatefibres. 

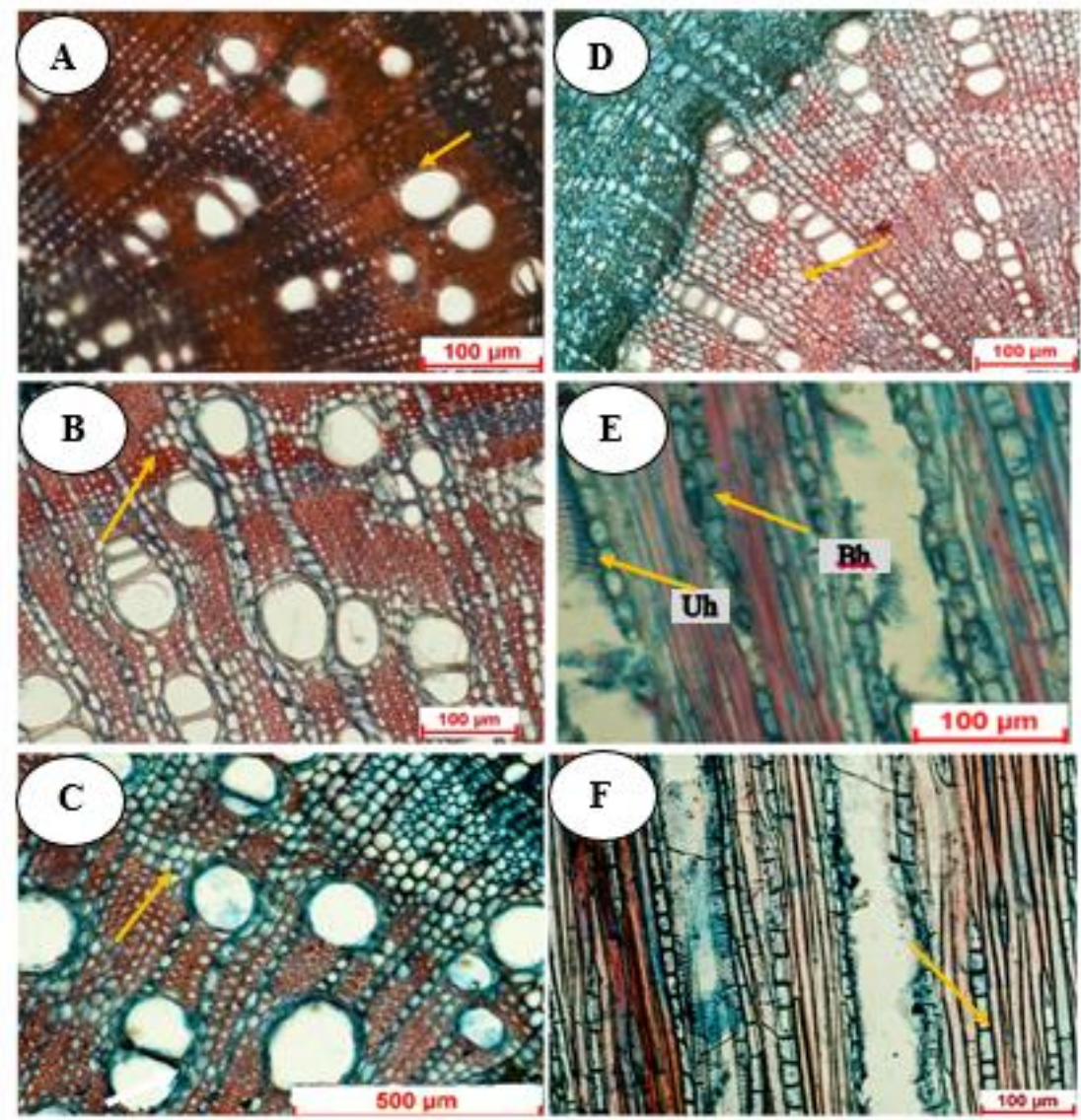

Plate (3): Diagnostic features in Terminalia species; (A-D) Paratracheal axial parenchyma, (A) vasicentric scanty in T. brownii, (B) Vasicentricaliform in T. laxiflora, (C) Vasicentricaliform- confluent to banded in T. arjuna; (D) vasicentric to banded in T. mantaly; type of rays and type of cells in rays; (E) uniseriate and biseriatehomocellular rays in T. laxiflora; (F) Uniseriateheterocellular ray $\mathrm{R}$ in $T$. catappa. (Abbreviations: $\mathrm{Bh}=$ Biseriatehomocellular; Uh= Uniseriaatehomocellular). 
Waly et al.
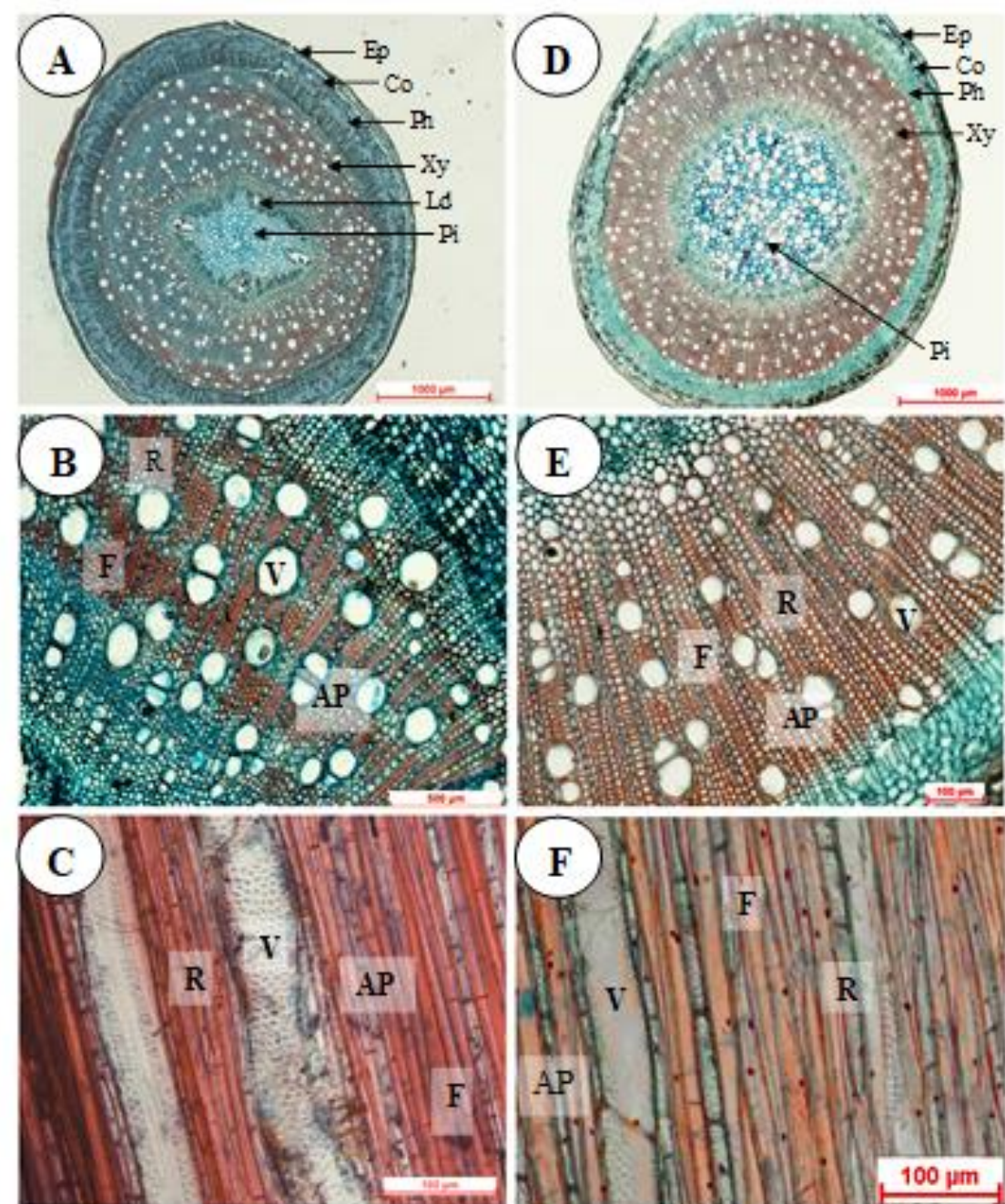

Plate (4): Microscopic stem sections in Terminalia species; (A-C) T. arjuna, (A, B) Transverse section, (C) Longitudinal section, (D-F) T. bellerica, (D, E) transverse section, $(\mathrm{F})$ longitudinal section. (Abbreviations: $\mathrm{Ap}=$ axial parenchyma; $\mathrm{Co}=$ cortex; $\mathrm{Ep}=$ epidermis; $\mathrm{F}=$ fibers; $\mathrm{Ld}=$ lysogenous duct; $\mathrm{Ph}=$ phloem $\mathrm{Pi}=$ pith; $\mathrm{R}=$ rays; $\mathrm{V}=$ vessels; $\mathrm{Xy}=\mathrm{xylem})$. 
Multivariate analysis of the stem
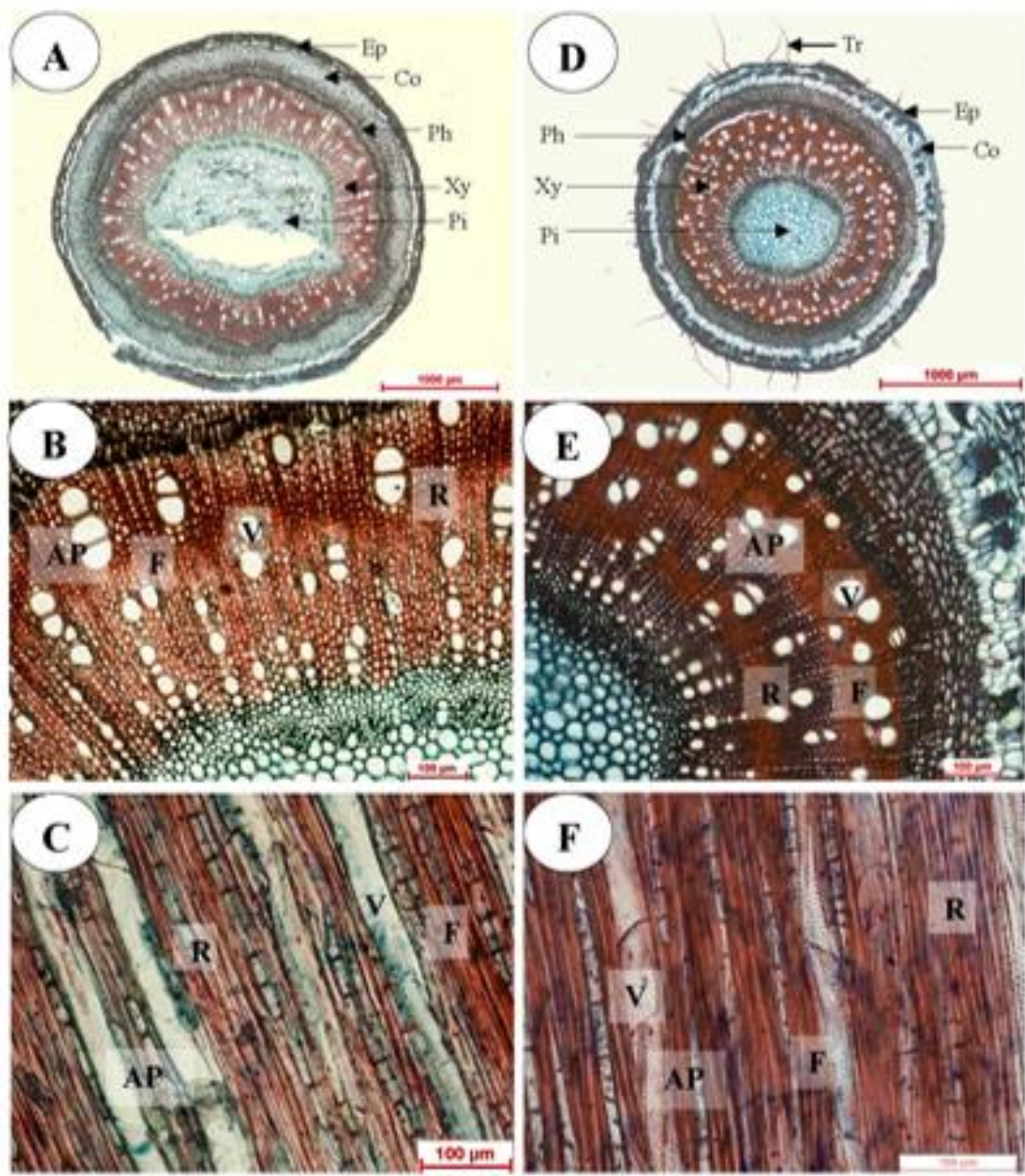

Plate (5): Microscopic stem sections in Terminalia species; (A-C) T. bentzoe, (A, B) Transverse section, (C) longitudinal section. (D-F) T. brownii, (D, E) Transverse section, (F) Longitudinal section. Abbreviations: Ap=axial parenchyma; $\mathrm{Co}=$ cortex $\mathrm{Ep}=$ epidermis; $\mathrm{F}=$ fibers; $\mathrm{Ph}=$ phloem; $\mathrm{Pi}=$ pith; $\mathrm{R}=$ rays; $\mathrm{Tr}=$ trichomes; $\mathrm{V}=$ vessels $; \mathrm{Xy}=$ xylem. 

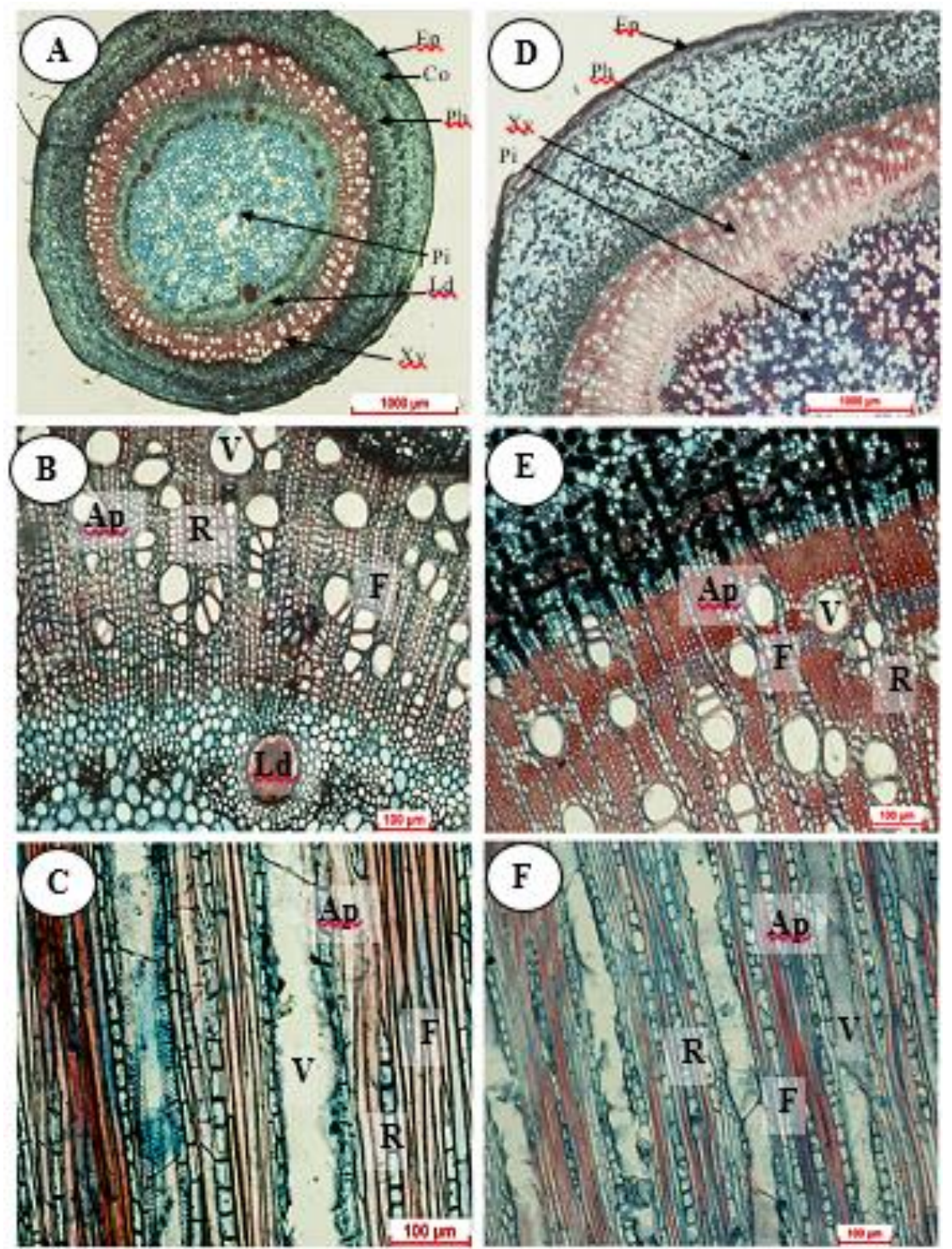

Plate (6): Microscopic stem sections in Terminalia species; (A-C) T. catappa, (A, B) Transverse section, (C) Longitudinal section. (D-F) $T$. laxiflora, (D, E) Transverse section, (F) Longitudinal section. (Abbreviations: $\mathrm{Ap}=$ axial parenchyma; $\mathrm{Co}=$ cortex; $\mathrm{Ep}=$ epidermis $\mathrm{F}=$ fibers; $\mathrm{Ld}=$ lysogenous duct; $\mathrm{Ph}=$ phloem; $\mathrm{Pi}=$ pith; $\mathrm{R}=$ rays; $\mathrm{V}=$ vessels; $\mathrm{Xy}=\mathrm{xylem}$ ). 
Multivariate analysis of the stem
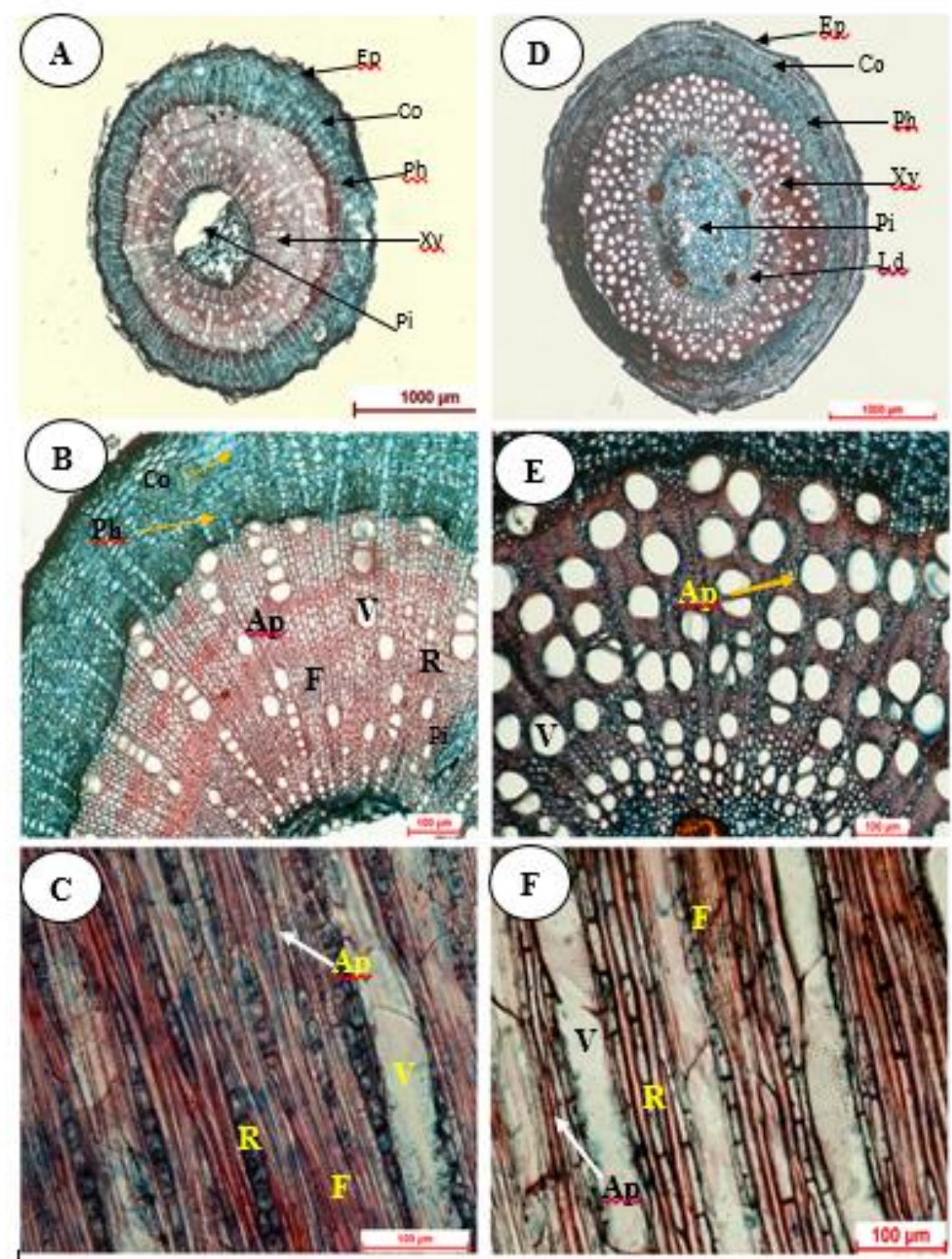

Plate (7): Microscopic stem sections in Terminalia species; (A-C) T. mantaly, (A, B) Transverse section, (C) Longitudinal section. (D-F) T. muelleri, (D, E) Transverse section, (F) Longitudinal section. (Abrrevations: Ep= epidermis; $\mathrm{Co}=$ cortex; $\mathrm{Ph}=$ phloem; Tan $=\operatorname{tannin} ; \mathrm{Xy}=\mathrm{xylem} ; \mathrm{Pi}=$ pith; $\mathrm{Ld}=$ lysogenous duct; $\mathrm{V}=$ vessels;Ap=axial parenchyma; $\mathrm{F}=$ fibers; $\mathrm{R}=$ rays). 
Waly et al.
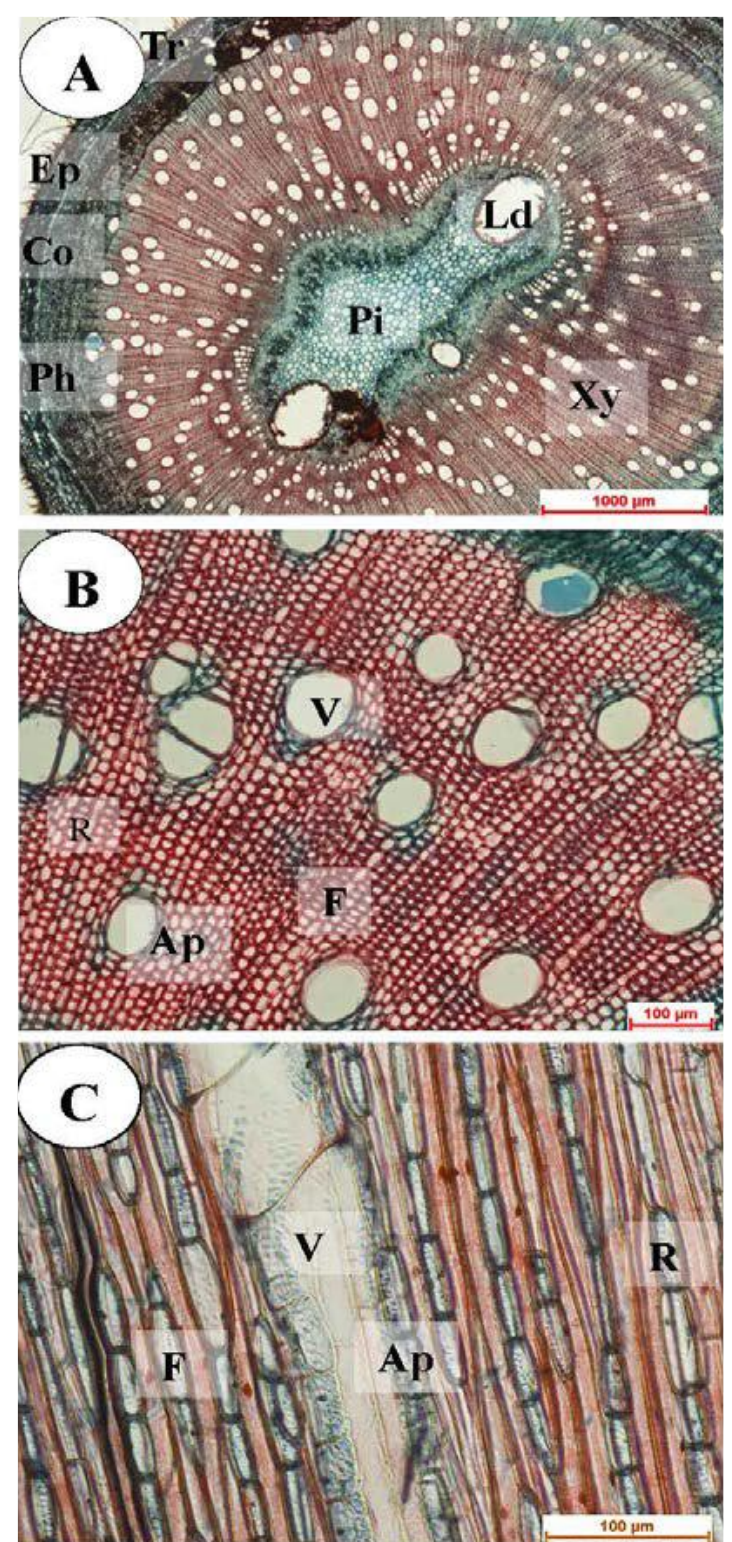

Plate (8): Microscopic stem sections in Terminalia myriocarpa; (A, B) Transverse section, (C) Longitudinal section. (Abbreviations: $\mathrm{Ap}=$ axial parenchyma; $\mathrm{Co}=$ cortex; $\mathrm{Ep}=$ epidermis; $\mathrm{F}=$ fibers; $\mathrm{Ld}=$ lysogenous duct; $\mathrm{Ph}=$ phloem; $\mathrm{Pi}=$ pith; $\mathrm{R}=$ rays; $\mathrm{Tr}=$ trichomes; $\mathrm{V}=$ vessels; $\mathrm{Xy}=\mathrm{xylem})$. 


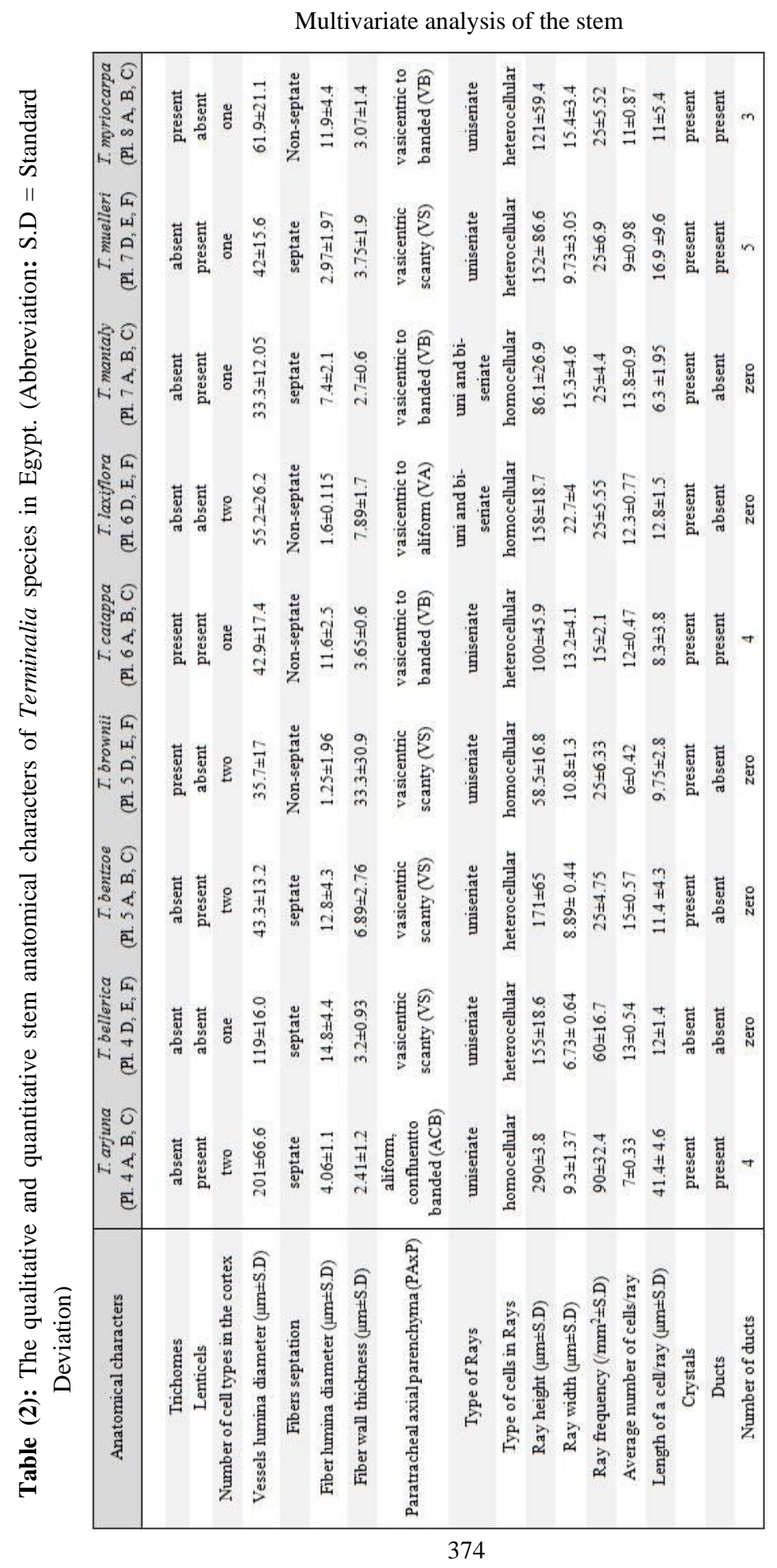




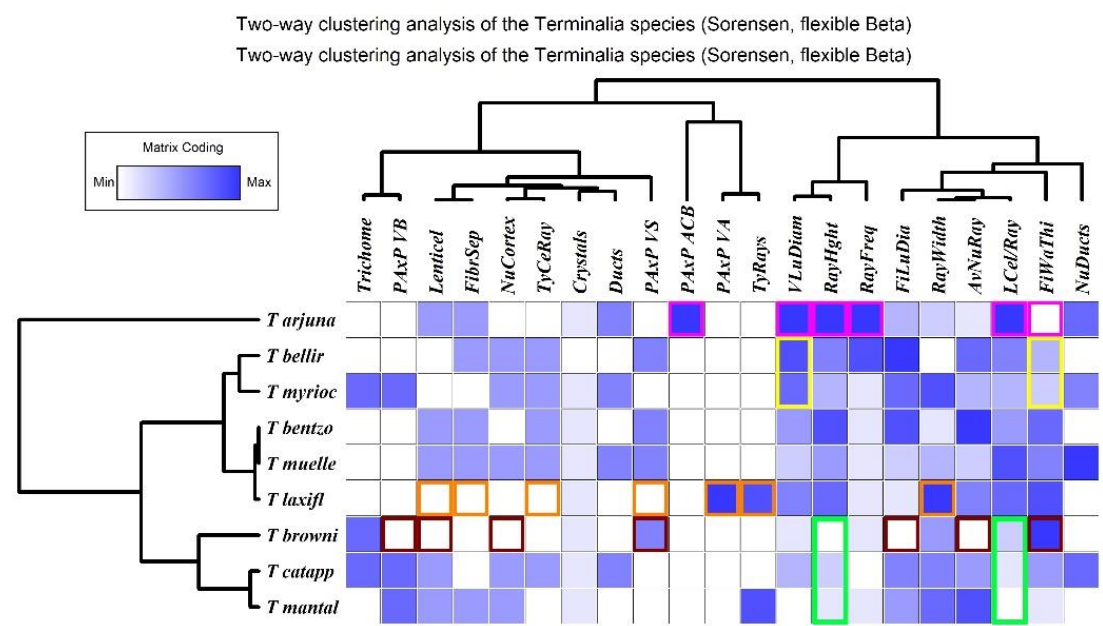

Diagram (1): Two-way clustering analysis of the nine studied Terminalia species using the Sorensen (Bray-Curtis) as a distance measure with the Flexible Beta as a linkage method, PC-ORD for window, version 5, depending upon the data of the stem anatomy in Table (1). (Abbreviations: AvNuRay $=$ Average number of cells/ray; FibrSep $=$ Fibres septation; FiLuDiam $=$ Fibre lumina diameter; FiWaThi $=$ Fibre wall thickness; LCel/Ray= Length of a cell/ray; NuCortex $=$ Number of cell types in the cortex; NuDucts $=$ Number of ducts; $\mathrm{PAxPACB}=$ Paratracheal axial parenchyma aliform confluent to banded; PAxPVA= Paratracheal axial parenchyma vasicentric to aliform; $\mathrm{PAxPVB}=$ Paratracheal axial parenchyma vasicentric to banded; PAxPVS= Paratracheal axial parenchyma vasicentric scanty; RayFreq= Ray frequency; RayHght= Ray height; TyRays $=$ Type of rays; TyCeRay $=$ Type of cells in Rays; VLuDiam $=$ Vessels lumina diameter).

2. Principal component analysis: The correlation between the diverse anatomical characters and the nine investigated species is shown in Diagram (2). Some characters are typically confined to definite species. The paratracheal axial parenchyma aliform confluent to banded (PAxPACB) and the vasicentric to aliform (PAxPVA) are restricted to T. arjuna and T. laxiflora, respectively. Meanwhile, the paratracheal axial parenchyma vasicentric to banded (PAxPVB) is distributed among the species of $T$. myriocarpa, T. catappa, and T. mantaly. Speaking of the distribution of the species in the plain, when the two pairs of T. bentzoe, T. muelleri, T. catappa, and T. mantaly stuck together, indicating their relationships anatomically, $T$. arjuna is precisely located in a distal position close to Axis 2 . The two-way hierarchical cluster analysis and the principal component analysis of the stem anatomical characters of the 9 investigated Terminalia species lead to the generalization of the following artificial key. 
Multivariate analysis of the stem

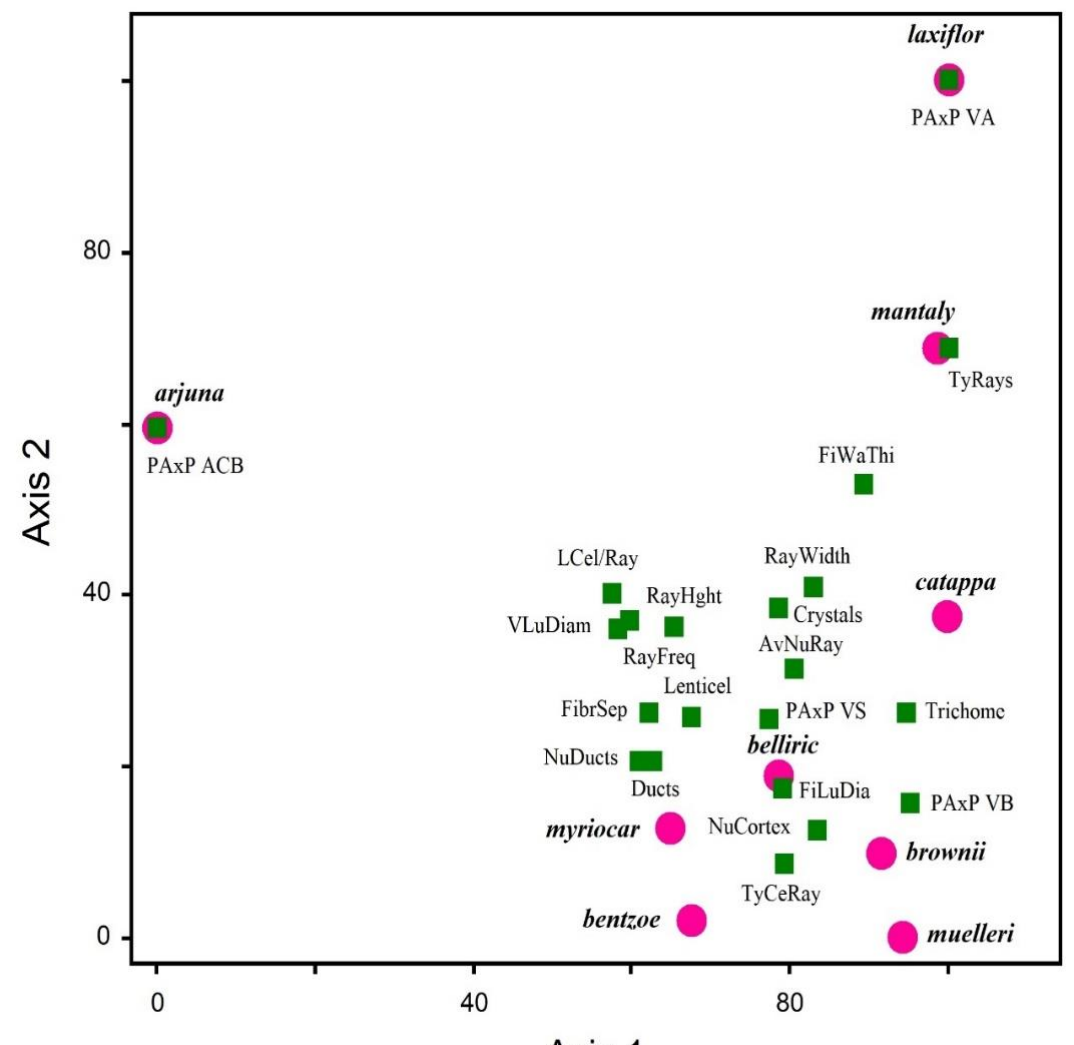

Axis 1

Diagram (2): PCA of the nine Terminalia species based on the investigated 21 anatomical characters. (For abbreviations, see Diagram 1)

The artificial key based on stem anatomical characters:

1. Paratracheal axial parenchyma aliform, confluent to banded, vessels lumina diameter $>200 \mu \mathrm{m}$, fiber wall thickness $<2.5 \mu \mathrm{m}$, ray height $\geq 280 \mu \mathrm{m}$, ray frequency $\geq 80 / \mathrm{mm}^{2}$, length of a cell/ray $>30 \mu \mathrm{m}$ T. arjuna

- Paratracheal axial parenchyma vasicentric scanty, vasicentric to aliform or banded, vessels lumina diameter $<200 \mu \mathrm{m}$, fiber wall thickness $\geq 2.5 \mu \mathrm{m}$, ray height $<280$ $\mu \mathrm{m}$, ray frequency $<80 / \mathrm{mm}^{2}$, length of a cell $/$ ray $\leq 30 \mu \mathrm{m}$ 2

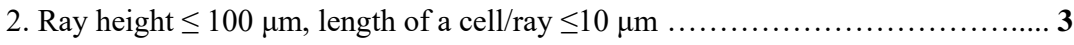

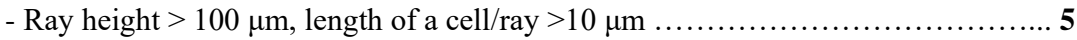

3. Paratracheal axial parenchyma vasicentric scanty; lenticels absent; two types of cells in the cortex; fiber lumina diameter $<5 \mu \mathrm{m}$; ray height $\leq 60$ $\mu \mathrm{m}$

..T. brownie 
Waly et al.

- Paratracheal axial parenchyma vasicentric to banded; lenticels present; one type of cells in the cortex; fiber lumina diameter $\geq 5 \mu \mathrm{m}$; ray height $>60 \mu \mathrm{m}$ 4

4. Uniseriate rays, heterocellular, fiber lumina diameter $>9 \mu \mathrm{m}$ and fiber wall thickness $3.65 \mu \mathrm{m}$ very thin-walled, fiber non-septate, ray frequency $10-20 / \mathrm{mm} 2$, trichomes present,

ducts present

T. catappa

- Uniseriate-and biseriate rays, homocellular, fiber lumina diameter $\leq 9 \mu \mathrm{m}$ and fiber wall thickness $2.7 \mu \mathrm{m}$ - thin- to thick-walled, fiber septate, ray frequency 20-30 $/ \mathrm{mm} 2$, trichomes absent, ducts absent

T. mantaly

5. Vessels lumina diameter $>60 \mu \mathrm{m}$, fiber wall thickness $<3.5 \mu \mathrm{m}$ 6

- Vessels lumina diameter $<60 \mu \mathrm{m}$, fiber wall thickness $>3.5 \mu \mathrm{m}$ 7

6. Paratracheal axial parenchyma vasicentric scanty, ray width $\leq 10 \mu \mathrm{m}$, ray frequency $50-70 / \mathrm{mm} 2$, vessels lumina diameter $>100 \mu \mathrm{m}$, fiber septate, trichomes, crystals, and ducts absent

T. bellerica

- Paratracheal axial parenchyma vasicentric to banded, ray width $>10 \mu \mathrm{m}$, ray frequency $20-30 / \mathrm{mm} 2$, vessels lumina diameter $<100 \mu \mathrm{m}$, fiber non-septate, trichomes, crystals, and ducts (3) present

T. myriocarpa

7. Paratracheal axial parenchyma vasicentric to aliform, uniseriate-and biseriate rays, homocellular, ray width $\geq 15 \mu \mathrm{m}$, vessels lumina diameter $>50 \mu \mathrm{m}$, fibre non-septate lenticels absent.

T. laxiflora

- Paratracheal axial parenchyma vasicentric scanty, uniseriate rays, heterocellular, ray width $<15 \mu \mathrm{m}$, vessels lumina diameter $<50 \mu \mathrm{m}$, fiber septate, lenticels present.

8. Ducts absent, two types of cells in the cortex, fiber lumina diameter $>5 \mu \mathrm{m}$ and fiber wall thickness 6.89- thin - to thick-walled

T. bentzoe

- Ducts present (5), one type of cells in the cortex, fiber lumina diameter $\leq 5 \mu \mathrm{m}$, and fiber wall thickness 3.75- thin- to thick-walled

T. muelleri

\section{DISCUSSION}

Anatomical analysis allowed us to create simplified and updated characteristics of Terminalia species and to provide additional qualitative and quantitative anatomical data on the species. In this sense, the study presented nine different species based on a more comprehensive data collection of the Terminalia stem vascular tissues.

The classification suggested by the multivariate analysis is more objective than traditional ones in that it could evaluate all characters at the same time. A lot of researchers used these techniques to perform their classifications. For instance, Lopes et al. (2020) used these techniques during their study on the stem anatomy of Selaginella subgenus Gymnogynum (P. Beauv.) West strand and Korall, 2016. 
Multivariate analysis of the stem

Furthermore, Waly et al. (2020) applied multivariate analyses to construct a key for the species of Terminalia in Egypt depending on the anatomical characters of the leaves. While, Yaradua et al. (2018) used it to study the genus Crotalaria L., 1753 in Nigeria. Also, Simo-Droissart et al. (2016) checked the morphometrics of Angraecum section Dolabrifolia (Pfitzer) Garay, 1973 (Orchidaceae, Angraecinae). Teleb and Salah-El-din (2014) used it to differentiate between the species of genus Ficus L., 1753 depending on the pollen morphology, while Rahman et al. (2013) used it to distinguish between species of genus Senna Mill., 1754from Bangladesh.

The Cluster Analysis (CA) and Principal Component Analysis (PCA) are the most commonly used techniques in numerical classifications. Both methods help in understanding the anatomical relations among the studied Terminalia species. CA segregates the various species depending on the similarities and dissimilarities of the qualitative and quantitative anatomical characters among the investigated species. PCA helps in understanding the relationship between these species depending on their spatial distribution within the graph and also clarifies which of the anatomical characters are confined to specific species.

The general anatomy of stem traits presumes useful definitions, not least because of the inevitable quantitative approach. The characters are equally crucial to comprise the broad spectrum of wood characteristics for any distinct taxon, and hence the degree of similarities and dissimilarities between various taxa. Therefore, there was an imperative demand to study wood anatomy, which gives distinct diagnostic characteristics and distinguishing different species (Gupta and Singh, 2005; Pande et al., 2005, 2007; Keshavarzi and Zare, 2006; Guimarães et al., 2007; Kaplan et al., 2007; Sharma et al., 2011 a, b; Stepanova and Oskolski, 2019). Consequently, the present research studies the differentiation between Terminalia species in Egypt based on the considerable variations of stem anatomy elements.

The stem description of Terminalia previously conducted by Metcalfe and Chalk (1950) and Tilney (2002) adequately described the wood elements of different species. This work discusses the anatomical differentiation between the nine species of genus Terminalia growing in Egypt concerning how much these characters are indeed reliable taxonomic markers in plant identification.

The paratracheal axial parenchyma is considered a significant parameter to differentiate between the studied species. It varied from vasicentric scanty in $T$. bellerica, T. bentzoe, T. brownii, and T. muelleri; vasicentric banded in T. catappa, $T$. mantaly, and T. myriocarpa; vasicentric to aliform in T. laxiflora while aliform confluent bands in T. arjuna. Van Vliet (1979) surveyed the characters of the wood anatomy of all genera of the Combretaceae except Meiostemon, among which 43 Terminalia species. It is similar to the current study in that he recorded that the parenchyma was mainly paratracheal, ranging from scanty vasicentric to paratracheal confluent bands, partly also diffuse and marginal. 
Waly et al.

Gupta and Singh (2005) examined 15 Indian Terminalia species and developed a dichotomous key based on macroscopic and microscopic features. The vessel diameter, axial parenchyma, septate and non-septate fibers were the most significant parameter for the differentiation between the studied Indian species. Their observations were similar to ours, where T. arjuna was with septate fiber, and T. myriocarpa showed crystals in the parenchyma. Furthermore, Singh and Sharma (2013) examined the variations of anatomical characters in four Terminalia (T. arjuna, T. bellerica, T. chebula, and T. myriocarpa). Their observations were similar to the current results. Besides, paratracheal parenchyma varied from vasicentric ( $T$. chebula), lozenge aliform (T. myriocarpa), and confluent (T. arjuna and T. bellerica). Also, ray characters were equally considered a significant parameter, including ray types, height, width, frequency, and the number of cells in each ray.

This study mutually agrees with van Vliet's results (1979); on one hand, it is found that the rays are mainly composed of procumbent cells with an infrequent square to erect marginal cells square and erect cells in some species, heterogeneous to homogeneous, exclusively uniseriate. On the other hand, he stated that rays might be multiseriate; uni- and biseriate in T. arjuna, 1 to 3-seriate in T. brownii and 1 - to 5seriate in T. catappa. Moreover, Ruwanpathirana (2014) carefully studied the principal characters and variation of some wood dimensions to differentiate between five species of Terminalia (T. arjuna, T. bellerica, T. catappa, T. chebula, and $T$. parviflora). His detailed description of wood elements is typical to that of the current study except for ray cell arrangement that was stated as mostly multiseriate and occasionally uniseriate in T. catappa. Moreover, these anatomical stem characters were similar to those observed in T. chebula by Ingle and Dhabe (2015). On the contrary, this study slightly differs from that of Singh and Sharma (2013), who concerned about the composition of rays forming of procumbent cells except for $T$. arjuna; rays were heterocellular and were composed of both procumbent and square cells.

Some other characters, including vessel diameter, fiber wall thickness, lumina and fiber septation, presence, and absence of trichome, lenticels, crystals, and ducts, were considered minor characters and may undoubtedly help to differentiate between species. Furthermore, van Vliet (1979) recorded solitary and radial multiples up to 5 or 6 vessels in T. arjuna, T. brownii, and T. catappa. Thin-walled tylosis or amorphous to granular contents was in some species only. Fibers were recorded thin to medium thick walls in most studied species, sometimes very thin or thick to very thick, septate or non-septate. In contrary to this study, he recorded crystals of the studied species with various types and frequencies, and sometimes occurred in several aggregates, large and rhomboidal, elongated rod or as isodiametric druses in rays and, or axial parenchyma cells, and sometimes absent.

Moreover, he properly recognized a considerable variation and overlapping of wood anatomical characters between the Terminalia species and all genera of the subtribe 


\section{Multivariate analysis of the stem}

Terminaliinae and some from other taxa. Observations of Singh and Sharma (2013) were similar to the current observations; the vessels were solitary and in radial multiples up two or three. Fibers were thin to thick-walled and prismatic crystals were found in the parenchyma in all species except $T$. chebula, and ray cells of $T$. myriocarpa.

The results support the observations offered by Tilney (2002) except for mucilage ducts which he did not mention their presence. However, Metcalfe and Chalk (1950) underlined the presence of mucilage canals in the intraxylary phloem and pith in several Terminalia species and to 'secretory spaces giving a mucilage reaction' as previously mentioned by Heiden (1893). It should be mentioned that the information taken from the 18 anatomical stem characters using IAWA Hardwood List Features have been recorded, for example, type of axial parenchyma, type of rays and fibers, diameter and frequency of vessels, length and frequency of rays, and more. Additionally, analysis of variance of the species' parameters showed that there were statistically significant differences in their wood elements (Tab. 1). Besides, the distinct characters of each species in this study assisted to differentiate among the nine species of Terminalia species by constructing an artificial key that summarized the extent of taxonomic similarity between the studied species.

Upon referring to interspecies variation in wood elements, van Vliet (1979) studied the average deviations of wood parameters and used them to distinguish between the studied Terminalia species. His measurements were similar to this study in average vessel diameter $(65-315 \mu \mathrm{m})$, but he used other wood parameters such as vessel diameter, average vessel member length and fibers length.

This study is in parallel to the observation of Singh and Sharma (2013), who recently observed fiber wall thickness of $T$. arjuna $(2.3 \mu \mathrm{m} \pm 0.9)$, ray height in $T$. arjuna $(242.4 \pm 84.2)$, and T. myriocarpa $(179.2 \pm 60.5)$, despite some uniformity in stem anatomy dimensions, the anatomical variation is distinct. There is a considerable variation in vessel diameter and ray width in all observed species, the fiber wall thickness in case of T. bellerica and T. myriocarpa $(2.1 \mu \mathrm{m} \pm 0.9$ and $2.2 \mu \mathrm{m} \pm 1.4$ respectively) and ray height of $T$. bellerica (209.4 $\mu \mathrm{m} \pm 69.7)$. This general description of wood elements is typical to this study; however, they naturally differ in the quantitative dimensions of wood elements: vessel diameter range, vessel frequency, ray width, and ray height ranges. The variations of some wood characters of the studies may be anticipated to the ecological influences (Campbell et al., 2016).

\section{LITERATURE CITED}

Akinsulire, O. P., Oladipo, O. T., Akinloye, A. J. and Illoh, H.C. 2018. Structure, distribution and taxonomic significance of leaf and petiole anatomical characters in five species of Terminalia (L.) (Combretaceae: Magnoliopsida). Brazilian Journal of Biological Sciences, 5 (10): 515-528. 
Waly et al.

AL-Mayah, A.A. 1983. The taxonomy of Terminalia (Combretaceae) and related genera. Ph.D. thesis, University of Leicester, Department of Botany, 553 pp.

Bircher, W. H. 1960. Gardens of the Hesperides. The Anglo-Egyptian Bookshop. Cairo, Egypt, 875 pp.

Campbell, G., Rabelo, G. R. and Cunha, M. D. 2016. Ecological significance of wood anatomy of Alseispickelii Pilg. \& Schmale (Rubiaceae) in a Tropical Dry Forest. Acta Botanica Brasilica, 30 (1): 124-130.

Chiapella, J. 2000. The Deschampsia cespitosa complex in central and northern Europe: a morphological analysis. Botanical Journal of the Linnean Society, 134: 495-512.

Delchevalerie, G. 1899. Les promenades et les jardins du Caire, vol. 1. France, Chaumes (S. \& M.) Publisher, 179 pp. (In French).

Edeoga, H. O., Omosun, G., Osuagwu, G. G. E. and Emezue, O. O. 2007. Microscopic Anatomy and Histochemistry of the Stem and Root of Some Mimosa species (Leguminosae- Mimosoideae). Asian Journal of Plant Sciences, 6(4): 688- 691.

Exell, A. W. and Stace, C. A. 1966. Revision of the Combretaceae. Boletim da Sociedade Broteriana, II (40): 5-25.

Gémez-Campo, C., Herranz-Sanz, J. M. and Montero-Riquelme, F. 2001. The genus Coincyu Rouy (Cruciferae) in south-central Spain revisited: a morphometric analysis of population structure. Botanical Journal of the Linnean Society, 135: 125-135.

Gill, B. S., Bir, S. S. and Singhal, V. K. 1982. Cytogenetics of some timber species of Terminalia Linn. (Combretaceae). Proceedings of the Indian National Science Academy, B48 (6): 773-790.

Guimarães, A., Kuster, R. M., Amaral, A. C. F. and Ferreira, J. L. P. 2007. Histological Study of the Leaf and Stem of the Amazonian Medicinal Mistletoe Cladocolea micrantha (Loranthaceae). International Journal of Botany, 3(2): 218-221.

Gupta, S. and Singh, M. 2005. Wood microstructure, ultrastructure and systematic study of Indian Terminalia. Indian Forester, 131 (8): 1041-1047.

Hamdy, R. 2010. Study of plant distribution in nine historic gardens in Egypt. Journal of Garden history, 38 (2): 267- 314. 
Multivariate analysis of the stem

Hamdy, R., Abd El Ghani, M. M., Youssef, T. L. and El-Sayed, M. 2007. The floristic composition of some historic gardens in the metropolitan of Cairo, Egypt. African Journal of Agriculture Research, 2 (11): 610-648.

Heiden, H. 1893. Anatomische Charakteristik der Combretaceen. Kessinger Publishing Bot. C. Blatt. 55: 353, 385: 56: 1, 65,129, 163, 193, 225.

Heywood, V. H., Brummitt, R. K., Culham, A. and Seberg, O. 2007. Flowering plant families of the world. Royal Botanic Gardens, Kew, 424 pp.

IAWA Committee. 1989. IAWA List of microscopic features for Hardwood Identification. IAWA Bulletin n.s., 10 (3): 219-332.

Imam, M. E. 1983. Timber trees in Egypt. Technical Bulletin, 1: 1-121.

Ingle, P. and Dhabe, A. 2015. Anatomical investigation of Terminalia chebula Retz. Phytotaxonomy, 15: 55-62.

Jansen, P. C. M., Westphal, E., Wulijarni-Soetjipto, N., Lemmens, R. H. M. J., Soerianegara, I. and Wong, W. C. 1995. Plant resources of South-East Asia 5(2). Timber trees: Minor commercial timbers. Backhuys Publishers, Leiden, $655 \mathrm{pp}$.

Johansen, D. A. 1940. Plant microtechnique. McGraw-Hill Book Company, New York, $523 \mathrm{pp}$.

Kaplan, A., Hasanoglu, A. and Ince, I. A. 2007. Morphological, anatomical and palynological properties of some Turkish Veronica species (Scrophulariaceae). International Journal of Botany, 3(1): 23-32.

Keshavarzi, M. and Zare, G. 2006. Anatomical study of Salicornieae Dumort. (Chenopodiaceae Vent.) Native to Iran. International Journal of Botany, 2(3): 278-285.

Lebrun, J. P. and Stork, A. 1991. Énumération des plantes à fleurs d'Afrique tropicale. Vol. 1. Généralités et Annonaceae à Pandaceae. Genève: Conservatoire et Jardin botaniques de la Ville de Genève, 254 pp.

Lopes, L. K. C., Góes-Neto, L. A. A. and Feio, A. C. 2020. Stem anatomy and its relevance for the taxonomic survey of Selaginella subg. gymnogynum (Selaginellaceae). Plant Systematics and Evolution, 306(2):13.

Metcalfe, C. R. and Chalk, L. 1950. Anatomy of the Dicotyledons. Vol. 1, Clarendon Press, Oxford, 724 pp. 
Waly et al.

McGaw, L. J., Rabe, T., Sparg, S. G., Jäger, A. K., Eliff, J. N. and van Staden, J. 2001. An investigation on the biological activity of Combretum spp. Journal of Ethnopharmacology, 75: 45-50.

Muschler, R. 1912. Combretaceae: A manual flora of Egypt. 2: 673-674, R. Friedlaender \& Sohn, Berlin.

Normand, D. and Paquis, J. 1976. Manuel d'identification des bois commerciaux. 2. Afrique guineo-congolaise. Centre Technique Forestier Tropical, Nogent-surMarne, 335 pp.

Ohri, D. 1996. Genome size and polyploidy variation in the tropical hardwood genus Terminalia (Combretaceae). Plant Systematics and Evolution, 200: 225-232.

Oladipo, O. T. and Akinloye, A. J. 2018. Structure, distribution and taxonomic significance of leaf and petiole anatomical characters in five species of Terminalia (L.) (Combretaceae: Magnoliopsida). Brazilian Journal of Biological Sciences, 5 (10): 515-528.

Pande, P. K., Negi, K. and Singh, M. 2005. Intra- and inter-species wood anatomical variation in Balau group of Shorea of Peninsula. Indian Forester, 131(8): 1041-1048.

Pande, P. K., Negi, K. and Singh, M. 2007. Wood anatomical variations in species of Shorea of Balau Group of Malay Peninsula- a tool for identification. Indian Forester, 133(6): 759-773.

Rahman, O., Rahman, M. and Begum, A. 2013. Numerical taxonomy of the genus Senna Mill. from Bangladesh. Bangladesh Journal of Plant Taxonomy, 20(1): 77-83.

Rajput, K. S. and Rao, K. S. 1999. Nucleated wood fibres in some members of Combretaceae. IAWA Journal, 20(1): 79- 83.

Ruwanpathirana, N. D. 2014. Use of wood characteristics in Identification of selected Terminalia species growing in Sri Lanka. Journal of Tropical Forestry and Environment, 4(2): 64-72.

Sarkar, B., Bera, S., Chowdhury, M. and Das, A. P. 2016. Variations in external and pollen morphological structures among four species of Terminalia L. (Combretaceae) from Terai-Dooars region of West Bengal, India. Pleione, 10(2): 344 - 350 . 
Multivariate analysis of the stem

Saxena, V. G., Mishra, K. K., Saxena, A. and Vishwakarma, K. K. 2013. A comparative study on quantitative estimation of tannins in Terminalia chebula, Terminalia bellerica, Terminalia arjuna and Saraca indica using spectrophotometer. Asian Journal of Pharmaceutical and Clinical Research, 6(7): 148-149.

Schmidt, E. M. L. and McCleland, W. 2002. Trees and Shrubs of Mpumalanga and Kruger National Park. South Africa Johannesburg: Jacana Media, 702 pp.

Sharma, C. L., Sharma, M., Carter, M. J. and Kharkonger, B. M. 2011a. Interspecies wood variation of Castanopsis species of Meghalaya. Journal of the Indian Academy of Wood Science, 8(2): 124-129.

Sharma, M., Sharma, C. L., Kharkonger, B. M. and Carter, M. J. 2011b. Wood anatomical variation in some species of Quercus of Meghalaya. Journal of the Indian Academy of Wood Science, 8(2): 152-157.

Sickenberger, E. 1901. Contributions à La Flore d' Egypte. Mémoire Institut Égyptien, 4 (2): 167-332.

Simo-Droissart, M., Sonke, B., Droissart, V., Micheneau, C., Lowry, P., Hardy, O., Plunkett, G.and Ste'vart, T. 2016. Morphometrics and molecular phylogenetics of Angraecum section Dolabrifolia (Orchidaceae, Angraecinae). Plant Systematics and Evolution, 302 (8): 1027-1045.

Singh, M. K. and Sharma, M. 2013. Wood anatomical variations in some Terminalia species of Assam. International Journal of Botany and Research, 3 (2): 13-18.

Sneath, P. H. and Sokal, R. R. 1973. Numerical Taxonomy: The principles and practice of numerical classification, 1st edition. San Francisco: W. H. Freeman and Co., 373 pp.

Stace, C. A. 2007. Combretaceae. In: Kubitzki, K. (Ed.). The families and genera of vascular Plants 9, Springer Verlag, Berlin, p. 67-82.

Stepanova, A. V. and Oskolski, A. A. 2019. Wood anatomy of Brabejum and Macadamia (Macadamiinae, Proteaceae). Botanica Pacifica, 8(2):1-7.

Tan, F., Hi, S., Zhong, Y., Gong, X. and Wang, Y. 2002. Phylogenetic relationships of Combretoideae (Combretaceae) inferred from plastid, nuclear gene and spacer sequences. Journal of Plant Research, 115: 475-481.

Teleb, S. and Salah-El-Din, M. 2014. Pollen morphology of some species of genus Ficus L. (Moraceae) from Egypt. Egyptian Journal of Botany, 54(1): 87- 102. 
Waly et al.

Tilney, P. 2002. A contribution to the leaf and young stem anatomy of the Combretaceae. Botanical Journal of the Linnean Society, 138: 163-196.

van der Veen, M. and Morales, J. 2015. The Roman and Islamic spice trade: New archaeological evidence. Journal of Ethnopharmacology, 167: 54-63.

van Vliet, G. J. C. M. 1979. Wood anatomy of the Combretaceae. Blumea, 25: 141223.

van Wyk, A. E. and van Wyk, P. 1997. Field guide to trees of southern Africa. Struik Publishers, Cape Town, 536 pp.

Waly, N., Moustafa, H., Hamdy, R. and Soliman, A. 2020. Anatomical Studies on the Genus Terminalia L. (Combretaceae) in Egypt I- Leaf Structure. Egyptian Journal of Botany, 60(3): 641-657.

Wickens, G. E. 1973. Flora of Tropical East Africa. Combretaceae: East African community. Royal Botanic gardens, Kew, 99 pp.

Yaradua, S., Alzahrani, D. and Bello, A. 2018. Numerical taxonomic study of the genus CrotalariaL. (Crotalarieae, Fabaceae) in Nigeria Variability, Taxonomy and Phylogeny. Biodiversity: Research and Conservation, 50: 25-32.

Youssef, T. A, ZL. and Hamdy, R. S. 2013 Timber Trees: Cultivated in Gardens and Planted Forests in Egypt. Egypt: Ministry of Agriculture and land Reclamation Under secretariat for Afforestation and Environment, $193 \mathrm{pp}$. 


\section{تحليل متعدد المتغيرات للخصائص التشريحية لسيقان نبات جنس في مصر Combretaceae عائلة Terminalia L.}

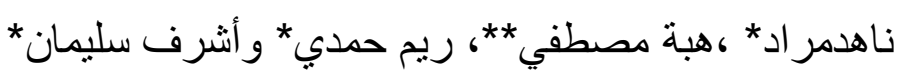

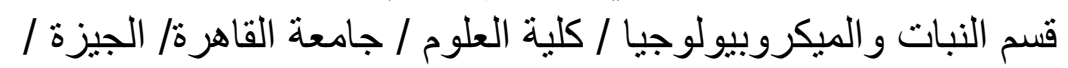

$$
\text { *مصر }
$$

* * الهيئة القومية للرقابة و البحوث الدو ائية/ القاهرة/ مصر

تأريخ الاستلام: 2021/04/20، تأريخ القبول: 2021/06/04، تأريخ النشر: 2021/6/20

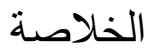

إجريت مقارنة بين الصفات التشريحية لسيقان تسعة أنو اع مختلفة

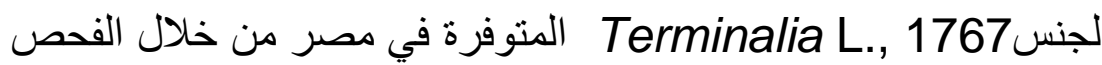

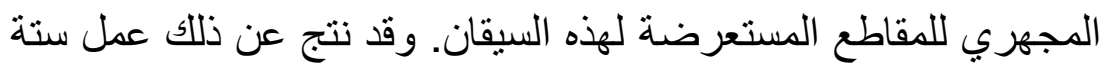

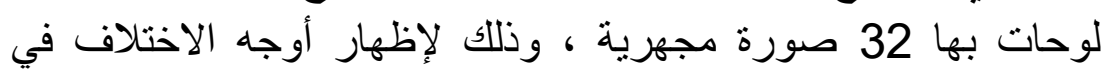

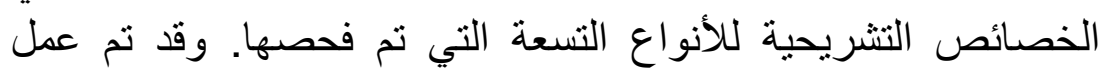

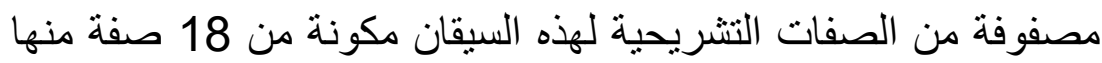

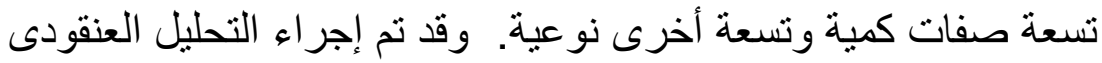

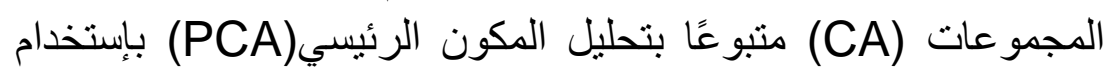

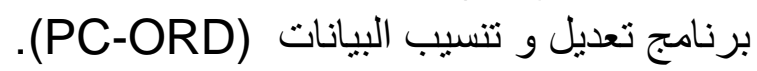

أظهرت النتائج اختلافات كبيرة وواضحة بين الأنواع قيد

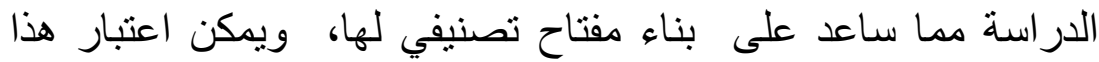

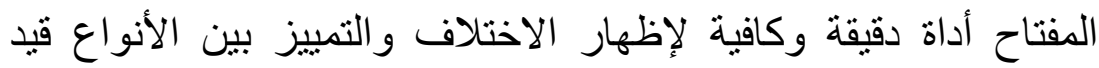

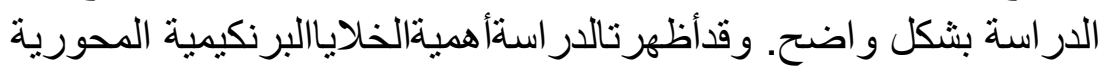

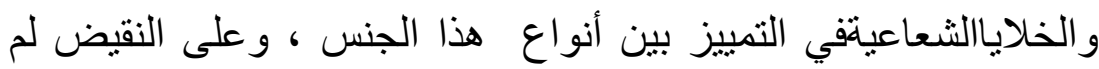

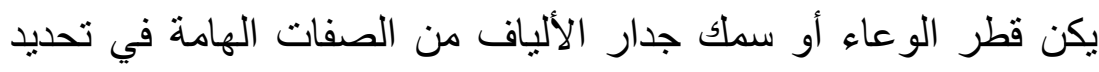

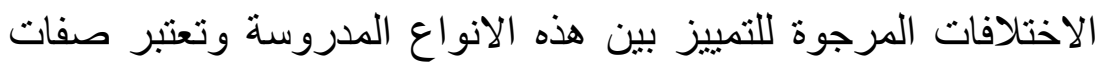


Waly et al.

ثانوية للتمييز و الفائدة المرجوة لهذه الدراسة هو التمييز بين هذه الأنواع

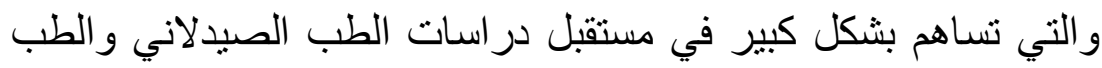

التقليدي لهذا الجنس. 